\title{
The effectiveness of a non-pharmacological intervention for weight gain management in severe mental disorders: results from a national multicentric study
}

\section{Efetividade de uma intervenção não farmacológica para manejo do ganho de peso em pacientes com transtornos mentais graves: resultados de um estudo multicêntrico}

\author{
Cecília Attux, ${ }^{1}$ Larissa C. Martini, ${ }^{1}$ Célia Maria de Araújo, ${ }^{1}$ Ana Maria Roma, ${ }^{1}$ André $F$. Reis, ${ }^{2}$ Rodrigo A. Bressan ${ }^{1}$ \\ ${ }^{1}$ Schizophrenia Program (PROESQ), Department of Psychiatry, Universidade Federal de São Paulo (UNIFESP), São Paulo, SP, Brazil \\ ${ }^{2}$ Department of Endocrinology, Universidade Federal de São Paulo (UNIFESP), São Paulo, SP, Brazil
}

\begin{abstract}
Objective: To evaluate the effectiveness of a non-pharmacological intervention for weight gain management in severe mental disorders. Method: An open, multicentre interventional study was conducted in 93 mental health services. Patients concerned with weight gain were included in this study and received a 12-week 1-hour group intervention focused on nutrition counseling, lifestyle, physical activity and self-esteem. Weight, waist circumference and blood pressure were measured before and after the intervention. Results: 1,071 patients were enrolled in the study, and $73.9 \%$ completed the 12 -week intervention. Significant weight loss (Mean difference: 0.41, CI 95\%: 0.18 to $0.64, \mathrm{p}=0.001$ ) and a significant BMI reduction (Mean difference: 0.13, CI 95\%: 0.04 to $0.22, \mathrm{p}=0.006$ ) were observed. During the intervention 37 (4.4\%) patients lost $>7 \%$ of their initial weight, $780(92.5 \%)$ maintained their weight, and $26(3.1 \%)$ of the patients had a meaningful weight gain $(>7 \%)$. There was a significant increase in the proportion of patients undertaking physical activity after the intervention $(70.8 \%, \mathrm{p}<0.001)$. Conclusion: In this 3-month open study we found a small weight and waist reduction, and increased physical activity practice, suggesting a trend towards anthropometric profile improvement. However, further randomized-controlled trials are necessary to evaluate the efficacy and clinical relevance of this psychosocial intervention for weight gain.
\end{abstract}

Descriptors: Weight gain; Mental disorders; Motor activity; Schizophrenia; Antipsychotic agents

\section{Resumo}

Objetivo: Avaliar a efetividade de uma intervenção não farmacológica no manejo do ganho de peso para pacientes com transtornos mentais graves. Método: Foi realizado um estudo aberto multicêntrico longitudinal em 93 serviços de saúde. Pacientes preocupados com o peso foram incluidos e participaram de uma intervenção em grupo de uma hora de duração durante 12 semanas com foco em educação alimentar, atividade física e autoestima. Peso, circunferência da cintura e pressão arterial foram avaliados antes e após a intervenção. Resultados: 1071 pacientes foram incluidos no estudo, 73,9\% completaram a intervenção. Foram observados diminuição de peso e indice de massa corporal significativos (peso: diferença da média: 0,41, IC 95\%: 0,18-0,64, $p=0,001$; indice de massa corporal: diferença da média: 0,13, IC 95\%: 0,04-0,22, $p=0,006)$. Após a intervenção, $37(4,4 \%)$ pacientes perderam mais que $7 \%$ do peso inicial, 780 (92,5\%) mantiveram o peso e $26(3,1 \%)$ dos pacientes apresentaram ganho de peso acima de 7\%. Houve aumento da proporção de pacientes que praticavam atividade física $(70,8 \%$, $p<0,001)$. Conclusão: Encontramos uma pequena redução de peso e cinturae aumento de atividade fisica, sugerindo uma tendência à melhora no perfil antropométrico. Ensaios clínicos controlados e randomizados são necessários para avaliar a eficácia e a relevância clínica dessa intervenção.

Descritores: Ganho de peso; Transtornos mentais; Atividade física; Esquizofrenia; Agentes antipsicóticos

\section{Introduction}

The increasing epidemic of obesity in the general population is associated with a variety of metabolic disturbances and serious health consequences such as cardiovascular disorders and diabetes mellitus. ${ }^{1}$ Patients with severe mental illness have a high prevalence of obesity in comparison with the general population. ${ }^{2,3}$ Several factors can be related to weight gain, such as poor dietary conditions, sedentary lifestyle and psychiatric medications such as antipsychotics, mood stabilizers and antidepressants. ${ }^{1,4}$

Although weight gain is an important clinical issue in the treatment of severe mental disorders, intervention studies in this context are scarce..$^{5-7}$ At present, there is limited evidence for the effectiveness and safety of current pharmacological interventions 
for weight control in patients taking antipsychotic medications. ${ }^{8-10}$ Behavioral interventions involving physical activity and nutritional advice have, however, proved beneficial for this population. ${ }^{4}$

In this study, we present and analyze results obtained from a national multicentric survey conducted to evaluate the effectiveness of weight gain management intervention in patients with severe mental disorders.

\section{Material and method}

\section{Study design}

We performed an open, multicentric and longitudinal study in 93 mental health services for inpatients and outpatients from community and private mental health services.

The detailed explanation of the Wellness Program to the patients was conducted in every institution by a mental health professional. After this explanation, the patients were invited to participate in the study. This study was approved by the UNIFESP Ethics Committee (1301/05) and all participants signed an informed consent form after having received a thorough explanation of the entire procedure.

\section{Intervention}

The Wellness Program is a 12 -week weight management intervention for patients with severe mental disorders. ${ }^{11}$ In the 1-hour weekly group sessions topics including dietary choices, lifestyle, physical activity and self-esteem were discussed with outpatients and their relatives (Table 1). The groups were led by mental health professionals - nurses, occupational therapists, psychologists and dieticians - who were trained and supervised by our team based at the Schizophrenia Program, Universidade Federal de São Paulo, Brazil, with support from Eli Lilly Brazil. The structure of the whole intervention was properly documented, and all professionals received a manual and a set of DVDs explaining the program. Patients were kept on their usual psychiatric treatment without any interference on the part of the participating researchers. Patients that attended fewer than six sessions were considered to have dropped out.

\section{Inclusion and exclusion criteria}

Inclusion criteria were: (1) patients should be between 18

\section{Table 1 - Wellness Program manual contents}

\begin{tabular}{ll}
\hline Session 1 & Program presentation, data assessment \\
Session 2 & Self- esteem \\
Session 3 & Healthy nutrition I \\
Session 4 & Healthy nutrition II \\
Session 5 & Physical activity I \\
Session 6 & Healthy nutrition III \\
Session 7 & Healthy nutrition IV \\
Session 8 & Physical activity II \\
Session 9 & Anxiety \\
Session 10 & Family's role \\
Session 11 & Physical activity III \\
Session 12 & Quiz \\
Session 13 & Evaluation \\
\hline
\end{tabular}

and 65 years old and have a diagnosis of severe mental disorder. Severe mental illness was defined by diagnosis, disability and duration, and included psychotic disorders such as schizophrenia, schizoaffective disorder, manic-depressive disorder, autism and other serious disorders such as major depression, panic disorder and obsessive-compulsive disorder. ${ }^{12}$ (2) Patients should show an interest in at least one of the group topics; (3) patients should be taking antipsychotic medication and/or a mood stabilizer. Exclusion criteria were: (1) not having any concern about weight or dietary habits; (2) being an acutely psychotic or clinically unstable patient. Patients with other clinical conditions - e.g. diabetes mellitus and hypertension - and taking other medications were not excluded from this study.

\section{Assessment}

Sociodemographic data, diagnosis, medication in use and family history of obesity, hypertension, diabetes mellitus and/or dyslipidemia were registered. Body mass index (BMI) and waist circumference were considered the indicators for obesity and body fat distribution. Weight, height, waist circumference and blood pressure were measured before and after the intervention. Weight was evaluated without shoes, with the individuals wearing light clothes; waist circumference was measured at the level of the navel. Weight gain was considered abnormal if there was an increase superior to $7 \%$ of the initial weight. ${ }^{13} \mathrm{BMI}$ is defined as the individual's body weight (in $\mathrm{kg}$ ) divided by the square of his height (in $\mathrm{m})\left[\mathrm{BMI}=\right.$ weight $(\mathrm{kg}) /$ height $\left.^{2}\left(\mathrm{~m}^{2}\right)^{2}\right]$. Measures were taken by the same investigator in all assessments. Physical activity levels were assessed by questions evaluating whether they were currently doing any kind of physical activity and the frequency of any physical activity. In the Wellness Program, all types of physical activity were considered such as housecleaning, dog walking, gardening, walking, swimming and physical exercise in general. Each patient had a record of their physical activity at baseline and after the intervention. During the program, the way in which physical activity was incorporated into their daily routine was recorded. Simple questions like "what you did before and what you do now" related to physical activity were noted in the records. All participants were encouraged to increase physical activity in their lives through simple actions like getting off the bus a few stops early, cleaning the yard, walking with friends. This was a qualitative measure that has intrinsic limitations since it was not feasible to monitor the amount of physical activity of each individual.

\section{Statistical analysis}

Data analysis was performed using the software SPSS 11.5. Normality was tested using Kolmogorov-Smirnov test. The Student's paired t-test was used to evaluate the statistical significance of weight, BMI, waist and blood pressure changes after the intervention. We performed a general linear model for weight and BMI using, as a cluster factor, the mental health institution and the point of assessment as a repeated measure to check if the treatment institution influences the main outcome. 
The McNemar test was used to analyze physical activity changes. We considered $\mathrm{p}<0.05$, two-tailed in all tests.

A categorical variable associated with weight change after intervention was created and included three classes of patients: patients with more than $7 \%$ of weight loss, patients whose weight was not significantly altered (i.e. who had less than $7 \%$ of weight gain or loss) and patients who had more than $7 \%$ of weight gain. This cutoff was established according to previous studies evaluating weight gain in schizophrenia. ${ }^{6,13}$ Waist was presented stratified by gender because of the clinical importance of this measure to diagnose metabolic syndrome.

\section{Results}

Ninety-three psychiatric services were given training, with an average of 11 patients per group. One thousand and seventyone patients were assigned to the intervention and their sociodemographic data and clinical characteristics are found in Table 2. The vast majority of the patients $(648,63.8 \%)$ had a diagnosis of schizophrenia or other psychotic disorder, and 278 $(27.4 \%)$ had a diagnosis of mood disorders. At baseline, 806 (80.9\%) patients were taking antipsychotic drugs: 272 (27.3\%)

Table 2 - Baseline patient demographics and clinical characteristics

\begin{tabular}{|c|c|c|}
\hline Variable & $\mathbf{n}$ & $\%$ \\
\hline \multicolumn{3}{|l|}{ Gender } \\
\hline Male & 384 & 35.9 \\
\hline Age & 40.5 (SD: 11.1) & - \\
\hline \multicolumn{3}{|l|}{ Marital status } \\
\hline Single & 640 & 60.2 \\
\hline Married & 268 & 25.2 \\
\hline Divorced & 126 & 11.8 \\
\hline Widow & 30 & 2.8 \\
\hline \multicolumn{3}{|l|}{ Race } \\
\hline Caucasian & 672 & 66.7 \\
\hline Afroamerican & 125 & 12.4 \\
\hline Asian & 13 & 1.3 \\
\hline Mixed race & 198 & 19.6 \\
\hline \multicolumn{3}{|l|}{ Education (years ) } \\
\hline None & 29 & 2.8 \\
\hline $1-8$ & 452 & 44.1 \\
\hline $9-11$ & 399 & 39 \\
\hline$>11$ & 144 & 14.1 \\
\hline \multicolumn{3}{|l|}{ Diagnosis } \\
\hline Schizophrenia / psychotic disorders & 648 & 63.8 \\
\hline Bipolar disorder & 190 & 18.7 \\
\hline Depression & 88 & 8.7 \\
\hline Other & 90 & 8.8 \\
\hline \multicolumn{3}{|l|}{ Drugs } \\
\hline First generation antipsychotics & 272 & 27.3 \\
\hline Second generation antipsychotics & 320 & 27.3 \\
\hline Association of antipsychotics & 214 & 21.5 \\
\hline Mood stabilizers & 403 & 40.4 \\
\hline Antidepressants & 106 & 10.7 \\
\hline Benzodiazepines & 112 & 11.3 \\
\hline Anticholinergics & 149 & 15.0 \\
\hline
\end{tabular}

were taking first-generation antipsychotics, 320 (32.1\%) were taking second-generation antipsychotic drugs, and 214 (21.5\%) were taking both second and first generation antipsychotics.

The majority of the patients $(794,73.9 \%)$ attended 6 or more sessions, with an average of 10.5 (SD: 2.1). However, 26.1\% dropped out with an average of 3.4 (SD: 1.2) attended sessions. Reasons for dropout included recurrence, declining to participate, personal issues, lost contact and others. No differences were found between patients who completed the intervention and dropouts regarding gender, age, BMI at baseline, use of antipsychotics and mood stabilizers $(\mathrm{p}>0.05)$.

After the intervention, patients showed a significant weight loss of 0.41 , CI 95\%: 0.18 to $0.64, \mathrm{p}=0.001$ and significant BMI reduction (Mean difference: 0.13 , CI 95\%: 0.04 to 0.22 , $\mathrm{p}=0.006$ ) - Table 3 . The treatment institution did not have a major influence on the main outcome reaching similar results for weight $(\mathrm{p}=0.003)$ and for BMI $(\mathrm{p}=0.022)$. Mean weight difference after controlling for the institutions was 0.39 (CI95\%:0.13 to 0.65 ) and BMI mean difference was 0.12 (CI 95\%: 0.017 to 0.228 ). During the intervention, $37(4.4 \%)$ patients lost more than $7 \%$ of their initial weight, $780(92.5 \%)$ maintained their weight (lost less than $7 \%$ or gained up to $7 \%$ of the initial weight) and only $26(3.1 \%)$ of the patients had a meaningful weight gain (> $7 \%)$. Patients taking 1st or 2 nd generation antipsychotic drugs showed no significant differences in weight loss $(p=0.904)$ or BMI reduction $(\mathrm{p}=0.658)$. Comparisons between patients with schizophrenia versus patients with mood disorders showed no significant differences in weight, BMI, waist or blood pressure $(p>0.05)$. After the intervention, both male and female patients presented a significant waist reduction (Table 3); $\mathrm{p}<0.001$.

There was a marked increase in physical activity after the intervention; at baseline $446(51.5 \%)$ patients were practising some kind of physical activity while after the intervention this number increased to $613(70.8 \%, \mathrm{p}<0.001)$.

\section{Discussion}

This is the largest real-world pragmatic multicentric national study of a non-pharmacological intervention for weight management involving 1071 patients with schizophrenia and other severe mental disorders from 93 health services distributed all over the country. We found a significant weight and waist circumference reduction. However, the magnitude of the reduction in weight $(0.41 \mathrm{~kg})$ and waist $(1 \mathrm{~cm}$ in female and $0.8 \mathrm{~cm}$ in male) was small and the clinical impact of this change is questionable.

Although some studies have focused on individual interventions for weight gain management, ${ }^{6,14,15}$ the purpose of our study was to evaluate a group intervention. This has implications if the intervention were to be implemented by the public health services, as the group aspect of the intervention would prove to be cost effective. The content of the intervention was similar to other published studies focusing on psychoeducation about healthy nutrition, physical activity and self-esteem. ${ }^{16,17}$ Although longer interventions are better for weight loss programs, several mental 
Table 3 - Clinical parameters at baseline and 3 months $(n=843)$

\begin{tabular}{|c|c|c|c|c|}
\hline Variable & Baseline (mean;SD) & 3 months (mean; SD) & Mean difference (CI 95\%) & p \\
\hline Weight (kg) & $83.6(18)$ & $83.1(18)$ & $0.41(0.18-0.64)$ & $<0.001$ \\
\hline BMI $\left(\mathrm{kg} / \mathrm{m}^{2}\right)$ & $31.2(5.6)$ & $31.07(5.6)$ & $0.13(0.04-0.22)$ & 0.006 \\
\hline Waist $(\mathrm{cm})$ Male & $108.3(14.5)$ & $107.5(13.1)$ & $0.83(0.22-1.43)$ & 0.008 \\
\hline Waist (cm) Female & $102.7(14.4)$ & $101.7(13.7)$ & $1.06(0.52-1.59)$ & $<0.001$ \\
\hline Systolic BP (mmHg) & $119.5(16.5)$ & $119.1(15.1)$ & $0.42(-0.6-1.48)$ & 0.433 \\
\hline Diastolic BP (mmHg) & $78.3(13.7)$ & $77.9(11.8)$ & $0.45(-0.46-1.36)$ & 0.332 \\
\hline
\end{tabular}

BMI: body mass index; BP: blood pressure; SD: standard deviation; $\mathrm{Cl}$ : confidence interval.

health studies have been reporting 12-week interventions similar to ours. ${ }^{14,15,17,18}$

Compliance with obesity treatment is hard to achieve even in the general population, considering that most obese people, if left untreated for 3 to 5 years, would probably gain $0.5-1 \mathrm{~kg}$ per year. ${ }^{19}$ The problem is even worse in patients with chronic and severe mental disorders due to unhealthy lifestyle, use of antipsychotics and negative symptoms. Even considering these conditions, our study had a good compliance rate, with $73.9 \%$ of patients completing the intervention, a value similar to those reported in other studies (which ranged from $49 \%$ to $100 \%$ ). ${ }^{14-16}$

We found an average decrease of $0.41 \mathrm{~kg}$ with a related reduction of $0.13 \mathrm{~kg} / \mathrm{m}^{2}$ in the BMI, $92.5 \%$ of the subjects having maintained their weight. These results are compatible with those reported by Littrel et al., who reported a $0.02 \mathrm{~kg}$ weight loss in patients who had attended group sessions. ${ }^{16}$ After the intervention, patients showed a significant waist reduction, similar to other studies. ${ }^{13,20}$

It is also important to remark that we observed an increase in physical activity after the intervention. This is relevant, as there is increasing evidence that modest physical activity can reduce the risk of cardiovascular diseases, independent of the weight status. ${ }^{21,22}$

While the results are encouraging, the study has some limitations, such as the relatively short period of follow-up (12 weeks) and the absence of a control group. However, patients have changed metabolic parameters and exercise habits in the short term. The results suggest that there is an improvement or maintenance of weight and BMI. The effectiveness of our intervention in preventing weight gain is, however, limited by the absence of a control group. The fact that the average age of participants was 40.3 and mean BMI was $31.3 \mathrm{~kg} / \mathrm{m}^{2}$ indicates that the majority of patients had already experienced weight gain, further limiting speculation about the effectiveness of the intervention in weight gain prevention because the weight changes are smaller in obese patients. The intervention was customized for this population and a randomized-controlled trial is necessary to evaluate the effects of the intervention in weight gain prevention.

The naturalistic design and the presence of a large and representative sample allow us to estimate which factors are, "in the real world", associated with weight gain complaints on the part of mental health patients. We have echoed the recent concerns highlighted in the literature, since the majority of the patients were taking 2 nd generation compounds in monotherapy $(320,32.1 \%)$ or combined with a 1 st generation antipsychotic drug $(214,21.5 \%)$. On the other hand, the data shows that weight gain is not restricted to treatment using 2 nd generation antipsychotic drugs, given that $27.3 \%$ of the patients were taking 1 st generation antipsychotic drugs and $19.2 \%$ were not taking antipsychotic drugs at all.

Weight management strategies are of great importance and are widely used in the general population. Interventions focused on populations with severe mental health disorders are greatly needed in order to implement healthy habits, prevent cardiovascular disorders and improve quality of life. ${ }^{23}$ This study has shown that the Wellness Program intervention is uncomplicated, feasible in a wide variety of mental health teams in Brazil, and it was found that the great majority of the patients maintained their weight. We are conducting a randomized controlled trial in this population to evaluate the effectiveness of the intervention in weight gain prevention.

\section{Acknowledgements}

Ana Paula Flora - S.A.A, Beatriz Petreche - Psy.D., Brisa Baptista - R.D., Daniela Figueiredo Canguçu - O.T.R, Denise Amino - M.D., Emiliana Mc Mullan - Psy.D., Fernanda de Almeida Pimentel - OTR, Hélio Elkis - M.D.,PhD, Maria das Graças M. Camargo - Psy.D., Mário Dinis Mateus - M.D.,M.Sc., Patrícia Leite Castro - Psy.D., Patrícia Tsunematsu - Psy.D., Vânia Regina Bressan - R.N., Eli Lilly do Brasil, and staff from the 93 institutions enrolled on this study. 


\section{Disclosures}

\begin{tabular}{|c|c|c|c|c|c|c|c|}
\hline $\begin{array}{l}\text { Writing group } \\
\text { member }\end{array}$ & Employment & $\begin{array}{l}\text { Research } \\
\text { grant }^{1}\end{array}$ & $\begin{array}{l}\text { Other research } \\
\text { grant or medical } \\
\text { continuous } \\
\text { education }\end{array}$ & $\begin{array}{l}\text { Speaker's } \\
\text { honoraria }\end{array}$ & $\begin{array}{c}\text { Ownership } \\
\text { interest }\end{array}$ & $\begin{array}{l}\text { Consultant/ } \\
\text { Advisory } \\
\text { board }\end{array}$ & Other $^{3}$ \\
\hline Cecília Attux & UNIFESP & $\begin{array}{l}\text { FAPESP }^{* * *} \\
\text { Eli-Lilly**}\end{array}$ & Eli-Lilly* & Eli-Lilly* & - & - & - \\
\hline $\begin{array}{l}\text { Larissa C. } \\
\text { Martini }\end{array}$ & UNIFESP & $\begin{array}{l}\text { CAPES }^{*} \\
\text { FAPESP }^{* * *} \\
\text { Eli-Lilly }^{* *}\end{array}$ & - & - & - & - & - \\
\hline $\begin{array}{l}\text { Célia Maria de } \\
\text { Araújo }\end{array}$ & UNIFESP & - & - & - & - & - & - \\
\hline Ana Maria Roma & UNIFESP & - & - & - & - & - & - \\
\hline André $F$. Reis & UNIFESP & - & - & - & - & - & - \\
\hline $\begin{array}{l}\text { Rodrigo A. } \\
\text { Bressan }\end{array}$ & $\begin{array}{l}\text { UNIFESP }{ }^{\star * *} \\
\text { IIEPAE*** }\end{array}$ & $\begin{array}{l}\text { FAPESP }^{* * *} \\
\text { CNPq }^{* * *} \\
\text { IIEPAE }^{* * *}\end{array}$ & $\begin{array}{c}\text { Novartis }^{* * *} \\
\text { Eli-Lilly } \\
\text { Janssen-Cilag } \\
\text { AstraZeneca*** }\end{array}$ & $\begin{array}{c}\text { Novartis } \\
\text { Eli-Lilly**} \\
\text { Janssen-Cilag } \\
\text { AstraZeneca* }\end{array}$ & - & $\begin{array}{c}\text { Janssen- } \\
\text { Cilag* }^{*} \\
\text { AstraZeneca* }\end{array}$ & $\begin{array}{c}\text { Eli-Lilly* } \\
\text { Janssen- } \\
\text { Cilag* }^{*} \\
\text { AstraZeneca* }\end{array}$ \\
\hline
\end{tabular}

* Modest

** Significant

*** Significant: Amounts given to the author's institution or to a colleague for research in which the author has participation, not directly to the author.

Note: UNIFESP = Universidade Federal de São Paulo; IIEPAE = Instituto Israelita de Ensino e Pesquisa Albert Einstein; FAPESP = Fundação de Amparo à Pesquisa do Estado de São Paulo; CAPES = Coordenação de Aperfeiçoamento de Pessoal de Nível Superior; CNPq = Conselho Nacional de Desenvolvimento Científico e Tecnológico.

For more information, see Instructions for Authors.

\section{References}

1. Wirshing DA. Schizophrenia and obesity: impact of antipsychotic medications. J Clin Psychiatry. 2004;65(Suppl 18):13-26.

2. Allison DB, Fontaine KR, Heo M, Mentore JL, Cappelleri JC, Chandler LP, Weiden PJ, Cheskin LJ. The distribution of body mass index among individuals with and without schizophrenia. J Clin Psychiatry. 1999;60(4):215-20.

3. Kupfer DJ. The increasing medical burden in bipolar disorder. JAMA. 2005;293(20):2528-30.

4. Hoffmann VP, Ahl J, Meyers A, Schuh L, Shults KS, Collins DM, Jensen L. Wellness Intervention for patients with serious and persistent mental illness. J Clin Psychiatry. 2005;66(12):1576-9.

5. Faulkner G, Soundy AA, Lloyd K. Schizophrenia and weight management: a systematic review of interventions to control weight. Acta Psychiatr Scand. 2003;108(5):324-32.

6. Alvarez-Jiménez M, González-Blanch C, Vázquez-Barquero JL, Pérez-Iglesias R, Martínez-Garcia O, Pérez-Pardal T, Ramírez-Bonilla ML, Crespo-Facorro B. Attenuation of antipsychotic-induced weight gain with early behavioral intervention in drug-naive first-episode psychosis patients: a randomized controlled trial. J Clin Psychiatry. 2006;67(8):1253-60.

7. Attux C, Martini LC, Reis AF, Bressan RA. Intervenções não farmacológicas para manejo do ganho de peso em pacientes com esquizofrenia em uso de antipsicóticos. Arq Bras Endocrinol Metabol. 2009:53(4):391-8.

8. Elkis H, Gama C, Suplicy H, Tambascia M, Bressan RA, Lyra R, Cavalcante S, Minicucci W. Brazilian Consensus on second-generation antipsychotics and metabolic disorders. Rev Bras Psiquiatr. 2008;30(1):77-85.

9. Werneke U, Taylor D, Sanders TA. Options for pharmacological management of obesity in patients treated with atypical antipsychotics. Int Clin Psychopharmacol. 2002;17(4):145-60.

10. Bushe C, Haddad P, Peveler R, Pendlebury J. The role of lifestyle interventions and weight management in schizophrenia. J Psychopharmacol. 2005;19(6 Suppl):28-35.

11. Attux C, Araújo CM, Roma, AM, Mateus M, Campagna L, Canguçu D, Bressan RA. Brazilian Wellness Program: results from first year. Int $J$ Neuropsychopharmacol. 2006;9(Suppl 1):S156.

12. National Advisory Mental Health Council. Health care reform for Americans with severe mental illnesses: report of the National Advisory Mental Health Council. Am J Psychiatry. 1993;150(10):1447-65.
13. Kinon BJ, Basson BR, Gilmore JA, Tollefson GD. Long-term olanzapine treatment: weight change and weight-related health factors in schizophrenia. $J$ Clin Psychiatry. 2001;:62(2):92-100.

14. Evans S, Newton R, Higgins S. Nutritional intervention to prevent weight gain in patients commenced on olanzapine: a randomized controlled trial. Aust NZ J Psychiatry. 2005; 39(6):479-86.

15. Mauri M, Castrogiovanni S, Simoncini M, Iovieno N, Miniati M, Rossi A, Dell'Agnello G, Fagiolini A, Donda P, Cassano GB. Effects of an educational intervention on weight gain in patients treated with antipsychotics. J Clin Psychopharmacol. 2006;26(5):462-6.

16. Littrell KH, Hilligoss NM, Kirshner CD, Petty RG, Johnson CG. The effects of an educational intervention on antipsychotic-induced weight gain. J Nurs Scholarsh. 2003;35(3):237-41.

17. Menza M, Vreeland B, Minsky S, Gara M, Radler DR, Sakowitz M. Managing atypical antipsychotic-associated weight gain: 12-month data on a multimodal weight control program. J Clin Psychiatry. 2004;65(4):471-77.

18. Kwon JS, Choi JS, Bahk WM, Kim CY, Kim CH, Shin YC, Park BJ, Oh CG. Weight management program for treatment-emergent weight gain in olanzapine-treated patients with schizophrenia or schizoaffective disorder: a 12 -week randomized controlled clinical trial. J Clin Psychiatry. 2006;67(4):547-53.

19. Williamson DF. Descriptive epidemiology of body weight and weight change in U.S. adults. Ann Intern Med. 1993;119(7 Pt 2):646-9.

20. Mc Kibbin CL, Patterson TL, Norman G, Patrick K, Jin H, Roesch S, Mudaliar S, Barrio C, O'Hanlon K, Griver K, Sirkin A, Jeste D. A lifestyle intervention for older schizophrenia patients with diabetes mellitus: A randomized controlled trial. Schizophr Res. 2006;86(1-3):36-44.

21. Blair SN, Kohl HW, Paffenbarger RS, Clark DG, Cooper KH, Gibbons LW. Physical fitness and all-cause mortality: a prospective study of healthy men and women. JAMA.1989;262(17):2395-401.

22. Lee CD, Blair SN, Jackson AS. Cardiorespiratory fitness, body composition, and all-cause and cardiovascular disease mortality in men. Am J Clin Nutr. 1999;69(3):373-80.

23. Kolotkin RL, Corey-Lisle PK, Crosby RD, Swanson JM, Tuomari AV, L'Italien GL, Mitchell JE. Impact of obesity on health-related quality of life in schizophrenia and bipolar disorder. Obesity. 2008;16(4):749-54. 